\title{
EFL Teachers' Perceptions of the Effectiveness of Online Professional Development in Higher Education in Saudi Arabia
}

\author{
Fatimah Yousef Alzahrani ${ }^{1} \&$ Dr. Abeer Sultan Althaqafi ${ }^{1}$ \\ ${ }^{1}$ English Language Institute (ELI), King Abdulaziz University (KAU), Jeddah, Kingdom of Saudi Arabia \\ Correspondence: Dr. Abeer Sultan Althaqafi, English Language Institute (ELI), King Abdulaziz University \\ (KAU), Jeddah, Kingdom of Saudi Arabia. E-mail: abalthagafi@kau.edu.sa
}

Received: November 28, 2019

Accepted: January 14, 2020 Online Published: January 25, 2020

doi:10.5539/hes.v10n1p121

URL: https://doi.org/10.5539/hes.v10n1p121

\begin{abstract}
This study aimed at examining EFL teachers' perceptions of the effectiveness of an OPD program provided by a Saudi University. The program lasted for almost one year, and consisted of different courses about teaching English language. An online questionnaire was sent to the teachers to examine their perceptions of the effectiveness of the program through examining teachers' perceptions of the significant features of the program, their learning in the program, and their use of the new knowledge and skills. Findings indicated limitations in teachers' positive perceptions of the features of the OPD courses, teachers' learning, and teachers' use of new skills and knowledge. Providers of OPD need to take into consideration teachers' needs and preferences, and the obstacles that might inhibit teachers' learning. Needs analysis might be helpful to discover their needs and preferences and solutions for the obstacles they face.
\end{abstract}

\section{Introduction}

There is a consensus in the literature about the effectiveness of continuing teacher professional development (TPD) in improving the teaching practices, consequently, improving students' outcomes. Desimone (2009) confirmed that "Many reforms rely on teacher learning and improved instruction to increase student learning; in fact, education reform is often synonymous with teachers' professional development (Sykes, 1996)" (p. 181). However, there are many obstacles which might inhibit TPD. Some of these obstacles are the busy schedules of teachers, the high cost, and providing qualified trainers. Online professional development (OPD) provides solutions to some obstacles to offering face-to- face PD, which are expense, access, and loss of valuable classroom time (Magidin de Kramer, Masters, O'Dwyer, Dash \& Russell, 2012). Reeves and Pedulla (2011) maintained that "online professional development (OPD) is proliferating in an effort to eliminate various barriers to high-quality PD" (p. 592).

In spite of the valuable features of OPD, there seems to be a lack of research studies that examine OPD in Arab countries, especially in Saudi Arabia. Most of OPD studies have been carried out internationally (e.g. Murugaiah et al., 2010; Kabilan, Adlina, \& Embi, 2011, Magidin de Kramer et al., 2012; Liu, 2012; Silvia, 2015; Alimirzaee \& Ashraf, 2016; McCall, 2018). Nevertheless, few studies have been conducted in some of the Arab countries, and they focused on the use of the internet by EFL teachers (e.g. Elmabruk, 2009; Kabilan \& Rajab, 2010). Kabilan and Rajab (2010) examined the utilization of the internet by Palestinian EFL teachers and its contribution to their professional learning, and Elmabruk (2009) examined the potential of the internet-based PD for Libyan EFL teachers by examining teachers internet skills and their attitudes towards internet-based PD. In fact, there is a need to research and investigate the effectiveness of OPD programs for EFL teachers in Arab and Saudi context. Therefore, the present study aims at filling this gap by examining EFL teachers' perceptions of the effectiveness of online professional development in the Saudi context. This study contributes to the extant literature by providing an insight into the effectiveness of OPD for EFL teachers in the Saudi context from teachers' perspectives. The results of the current study can serve as a basis for designing effective and meaningful OPD programs. Findings can also inform teachers educators of EFL teachers' needs, beliefs and attitudes, and highlight the factors that influence teachers' willingness to participate in OPD, and the obstacles they might face in OPD.

\section{Research Questions}

The main research question of the study is: 


\subsection{What are teachers' Perceptions of the Effectiveness of the OPD courses?}

In order to answer this research question, three sub-research questions are addressed:

a- What are teachers' perceptions of the features of the OPD courses? (Features include likability, content, duration, structure, and interaction)

b- What is the impact of OPD courses on teachers' learning?

c- How can OPD courses enhance teachers' classroom practices?

\section{Literature Review}

\subsection{Guskey's (2000) Model}

Guskey (2000) developed a model to evaluate the effectiveness of teacher professional development. According to Guskey' (2000) model, efficient professional development evaluation requires collecting and analyzing five levels of information (Guskey, 2002). The five levels are: (1) participants' reactions (satisfaction of the participants with the PD experience), (2) participants' learning (new skills and knowledge), (3) organization support and change (the support of organization for change), (4) participants' use of new knowledge and skills (implementation), and (5) student learning outcomes (Guskey, 2002). These five levels follow a hierarchical arrangement in the model starting from the simple to more complex levels, and in each following level, the procedure of collecting evaluation information needs more resources and time (Guskey, 2016).

Guskey's (2000) model was an expansion of an evaluation model developed by Kirkpatrick's $(1959,1998)$ model for evaluating training programs. Kirkpatrick and Kirkpatrick (2006) identified four reasons for the importance of evaluating participants' reactions. Firstly, it provides valuable feedback for evaluating the program, and suggestions to improve future programs. It informs the trainees that their feedback is valuable for trainers and for evaluating the effectiveness of the program. It provides managers and who concern about the program with overall quantitative information about the program. Lastly, it provides quantitative information that can be utilized to design standards for future programs. Additionally, Guskey (2016) emphasized that "positive reactions from participants are usually a necessary prerequisite to higher-level evaluation results" (p. 32). Questions of this level basically focus on participants' satisfaction and likability, and their reactions to the activities, the materials, the information, the leader...etc. (Guskey, 2016).

Guskey's (2000) Model has been adopted widely in evaluating PD and OPD (e.g. Stahl, 2012; Silvia, 2015). For instance, Stahl (2012) adopted Guskey's (2000) model to examine the effectiveness of a TPD program. He utilized Lowden's (2005) survey which was developed to address Guskey's five levels of evaluative information. By following the design of Stahl's (2012) study, the researcher utilized Guskey's (2000) Model as a framework for the present study. In addition, the questionnaire developed by Lowden's (2005) were utilized to examine the effectiveness of the OPD program from teachers' perspectives, which was widely adopted to evaluate teachers' PD and OPD (e.g. Stahl, 2012; Garbe, 2012).

\subsection{Core Features of Effective Professional Development}

Desimone (2009) argued that "Understanding what makes professional development effective is critical to understanding the success or failure of many education reforms" (p. 181). Therefore, he proposed the core conceptual framework, based on his synthesis of empirical research, which comprises "the core features of effective professional development" (Desimone, 2009, p. 181). These features are:

- Content focus

- Active learning

- Coherence

- Duration

- Collective participation.

Content focus means PD should focus on the skills and knowledge that is needed to carry out day-to-day teaching, duration means that activities of PD should have sufficient duration to allow engagement and knowledge and instructional change, active learning means the opportunities to engage teachers actively in meaningful practice, planning, and discussion during the PD experience and their day-to-day work, coherence means "the connection between the PD activity and the reality of the classroom", and finally collective participation means "the opportunity for participants to undertake PD with others from the same school or group that sets up potential for interaction and discourse, which can be a powerful form of learning" (Main \& Pendergast, 2017). As shown in (Figure 1), Desimone (2009) explained the relationship between these features of professional development and teachers' beliefs and knowledge, instructional practices, and students' learning 
outcomes as follows:

1- First, teachers attend effective professional development experience that involves the five core features.

2- Secondly, professional development experience develops teachers' skills and knowledge or change their beliefs and attitudes.

3- Then, teachers implement their new skills and knowledge, beliefs and attitudes to enhance the content of their teaching or their pedagogical approach or both.

4- Finally, the instructional changes made by teachers improve the learning outcomes of students.

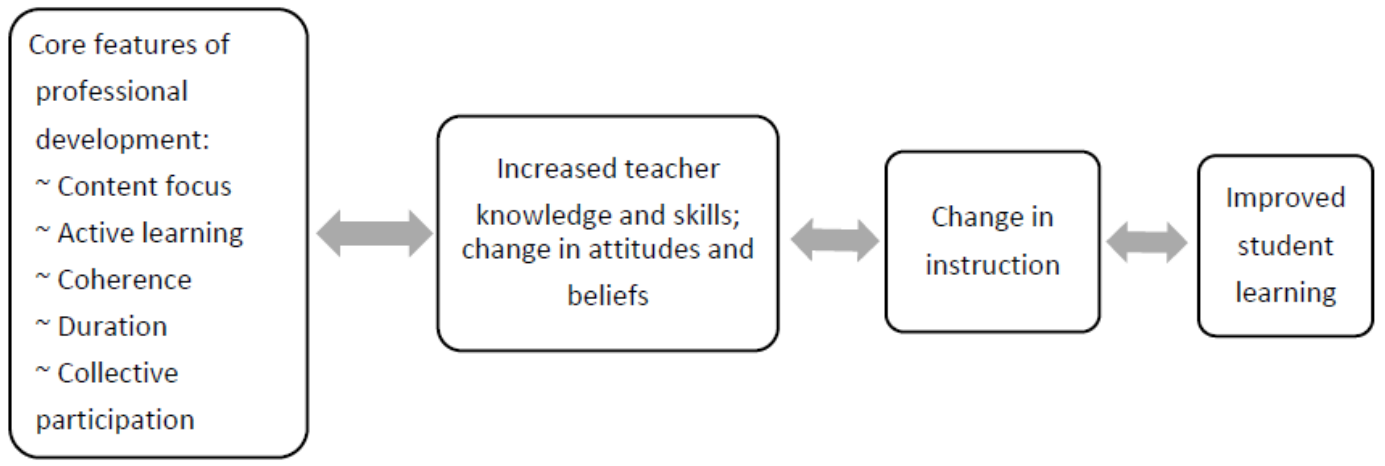

Figure 1. The Core Conceptual Framework (Desimone, 2009, p. 185)

This model has been widely adopted to design and evaluate PD (e.g. Garbe, 2012; Main and Pendergast, 2015). Main and Pendergast (2015) developed a survey tool to examine teachers' perceptions of the five core features of effective professional development which were identified by Desimone (2009). The survey consisted of 38 items that address the five core features of effective PD which are content focus, active learning, coherence, duration, and collective participation. The instrument was administrated to more than 45 teachers who participated in a professional development program to gain a "snapshot" into the effectiveness of the PD the researchers conducted and "to gain insights into the comprehensiveness and usefulness of the instrument", which is the main focus of their study (Main \& Pendergast, 2015). The researchers concluded that this survey will be useful for evaluating PD programs (Main \& Pendergast).

Garbe (2012) examined the relationship between these core features in an OPD program and teachers' learning. Findings revealed that teachers perceived the online courses to have the core features of effective PD, and they reported that they developed their knowledge and skills as a result of the OPD.

\subsection{Interaction in $O P D$}

Moore (1989) distinguished between three types of interaction in online learning which are learner-instructor interaction, learner-learner interaction, and learner-content interaction. In learner-instructor interaction which is greatly desired by learners, the instructor teaches the curriculum or the content, arouses or maintains the interest of students in the content, and motivates them to learn (Moore, 1989). Learner-content interaction is "the process of intellectually interacting with the content that results in changes in the learner's understanding, the learner's perspective, or the cognitive structures of the learner's mind", and learner-learner interaction is the interaction among learners, which Moore (1989) considered as an essential and valuable learning resource (Moore, 1989, p. 2). Moore (1989) emphasized that educators of distance education need to plan for all these three types of interaction and to maximize the effectiveness of each one. He also added that the major weakness of several programs in distance education is their adherence to one kind of medium, which probably leads to only one type of interaction.

Hillman et al. (1994) explained a fourth type of interaction which is learner-interface interaction, that allows learners to interact with content, instructor, and other students. Hillman et al. (1994) defined learner- interface interaction as "the process of manipulating tools to accomplish a task" (p. 5). He asserted that successful interaction depends highly on learners' feeling of comfort when working with the delivery system, and learners "cannot begin to deal with the content of the instruction if he or she is unable to first interact with the interface" (p. 6-7). Therefore, distance education providers need to acknowledge the effect of learner- interface interaction, and plan for it to ensure the effectiveness of other forms of interaction, and the success of learners' distance education (Hillman et al., 1994). 


\subsection{Previous Studies about OPD for English Language Teachers}

Some OPD programs are accompanied by different forms of face to face professional development models. OPD alos is provided in different forms such as paced or self-paced OPD, and it includes several synchronous and asynchronous activites such as online conferencing, online activites, and online communication. There are many studies have been conducted to examine the different forms of OPD for English language (EL) teachers (e.g. Elmabruk, 2009; Kabilan \& Rajab, 2010; Murugaiah et al., 2010; Kabilan, Adlina, \& Embi, 2011, Magidin de Kramer et al., 2012; Liu, 2012; Silvia, 2015; Alimirzaee \& Ashraf, 2016; McCall, 2018).

OPD is an effective form of teachers' education that can improve the instructional skills of EL teachers. McCall (2018) examined perceptions of content teachers towards an OPD program in public schools of United States that included large number of English language learners. Teachers confirmed that the online program developed their preparation skills for the lessons that are provided for EL learners in the content classrooms.

On the other hand, Silvia (2015) examined EL teachers' attitudes from different contexts (India, Russia, Brazil, Italia, USA, Indonesia, and Turkey) towards OPD courses provided by the Coursera platform. Teachers' attitudes were examined based on the five levels of information that identified by Guskey (2000); (1) participants' reactions, (2) participants' learning, (3) organization support and change, (4) participants' use of new knowledge and skills, and (5) student learning outcomes. Generally, teachers had positive attitudes towards the OPD experience. However, they lack the institutional support of their OPD. They also reported that the OPD affected positively their instructional practices and their students' learning.

Developing English language teachers' instructional skills and knowledge through OPD has a significant impact on enhancing EL learners' achievements and progress. Through a quasi-experimental research, Magidin de Kramer et al. (2012) explored the impact of OPD program on the instructional practices and content knowledge of English language arts teachers and the practices and content knowledge of their students. The program consisted of online workshops and online discussions among the teachers. It introduced the most effective teaching practices for enhancing reading comperehnsion skills, teaching writing, and vocabulary instruction. The findings suggested that the online professional program had a significant effect on teachers' content knowledge and on their writing and vocabulary teaching practices, and on students' reading comperehnsion skills.

OPD can foster meaningful and constructive communication among EL teachers through exchanging knowledge and experiences, thus, it promotes teachers' awareness, knowledge, and instructional skills. Liu (2012) fond that Taiwanese preservice and in-service EFL teachers perceived engaging in an online videocase discussion community as a useful professional learning experience. Moreover, in an experimental study, Alimirzaee and Ashraf (2016) examined the impact of online peer knowledge sharing among Iranian EFL teachers on their professional development. The expermintal group who were involved in an online discussion gained higher scores in the post-test of teaching knowlege test than the control group who received the same instructions without any knowledge sharing.

Moreover, Kabilan, Adlina, and Embi (2011) examined the effect of an online collaborative project that involved online discussion on Malaysian English language teachers and how it enhanced their professional development. They found that EFL teachers confrimed their meaningful OPD experience which provided them with a valuable opportunity to exchange and share their teaching knowledge and experiences.

Nowadays, technology becomes an essential element in EL teaching. Incorporating technology in the EL classroom can motivate students and create effective and enjoyable learning experience. OPD can be a significant opportunity for EL teachers to develop their technical skills and IT competence. Murugaiah et al. (2010) examined engaging Malaysian English language teachers of Smart School in online community of practice through blogging to share their experiences and knowledge. The results revealed that teacher interaction through online blogs was useful to expose teachers to different technical skills that are substantial for implementing computer-assisted teaching, and to develop these skills.

In the Arab context, Kabilan and Rajab (2010) investigated how using the internet by EFL teachers in Palestine contributed to their professional development. Despite the barriers that EFL teachers' faced regarding the internet facilitatities and accessibilities, teachers confirmed its significant contribution in promoting their professional learning through sharing knowledge with other teachers, and through searching for information in the TESL field. Another study conducted in the Arab context was carried out by Elmabruk (2009) which aimed at exploring the potential of internet-based PD for Libyan EFL teachers. Results showed that despite the intermediate level of teachers` internet skills, they maintained encouraging positive attitudes to internet-based PD, which is a good indicator for the potential of internet-based PD for Libyan EFL teachers. 


\section{Methodology}

\subsection{Participants}

The target population of the study was female EFL teachers of English Language Institues of two Saudi universities who received OPD program, and they were about 200 teachers. The program lasted for almost one year. The sampling process of the quantiative and quantitative data was conveinance sampling because the selection of the participants was based on their availability and their willingness to participate (Dörnyei, 2007). The questionnaire was sent to all the faculty members of the ELI at the two universities, and 52 responses were received which comprised approximatly $15 \%$ of the population.

\subsection{Instrument}

An online questionnaire was used to evaluate the effectiveness of OPD courses from teachers' perceptions. The items were borrowed from published questionnaires that examined OPD (Lowden, 2005, as cited in Stahl, 2012; Rizzuto, 2015; Main \& Pendergast, 2015).

\subsection{Reliability and Validity}

Cronbach's alpha coefficient was calculated to assess the internal consistency of the scale, thus the reliability of the Likert scale. The value of Cronbach's alpha was .91 which suggested very good internal consistency and reliability (Pallant, 2011).

\subsection{Cronbach's Alpha}

Table 1.

\begin{tabular}{ccc}
\hline \multicolumn{3}{c}{ Reliability Statistics } \\
\hline Cronbach's Alpha & Cronbach's Alpha Based on Standardized Items & N of Items \\
\hline .911 & .918 & 20 \\
\hline
\end{tabular}

To ensure the validity of the questionnaire, it was piloted by a Ph.D. holder in education, and an expert and researcher in TESOL field. It was also piloted by three EFL teachers who are master's students in TESOL.

\subsection{Ethical Consideration}

Before starting the data collection process, the researcher received approval forms from the two Saudi universities. Additionally, the questionnaire was anonymous and teachers' identities cannot be identified, in order to ensure that teachers feel safe expressing their opinions about the OPD courses.

\section{Data Analysis and Results}

\subsection{Respondents' Demographic Information}

The descriptive statistics were calculated for the respondents' demographic information with regard to nationality, level of education, age, and the teaching year in which they participated in the online courses (e.g. first year, second year, etc.). All the teachers were female and 55. $8 \%$ of them were Saudi while $44.2 \%$ of the teachers were non-Saudi from different nationalities. Regarding teachers' level of education, 38. $5 \%$ of the teachers were bachelor's degree holders, $53.8 \%$ were master's degree holders, and $7.7 \%$ were doctorate's degree holders. Also, $21.2 \%$ of teachers were aged $20-30,46.2 \%$ of teachers were aged $30-40,17.3 \%$ of teachers were aged $40-50$, and $15.4 \%$ of teachers were aged $50+$.

Table 2. Respondents' Demographic Information

\begin{tabular}{llll}
\hline & Demographic Information & Number & Percentage \\
\hline Nationality & Saudi & 29 & $55.8 \%$ \\
Level of education & Non-Saudi & 23 & $44.2 \%$ \\
& Bachelor's degree & 20 & $38.5 \%$ \\
& Master's degree & 28 & $53.8 \%$ \\
Age & Doctorate's degree & 4 & $7.7 \%$ \\
& $20-30$ & 11 & $21.2 \%$ \\
& $30-40$ & 24 & $46.2 \%$ \\
& $40-50$ & 9 & $17.3 \%$ \\
& $50+$ & 8 & $15.4 \%$ \\
\hline
\end{tabular}




\subsection{The Main Research Question of the Study}

\subsubsection{What Are the Teachers' Perceptions of the Effectiveness of the OPD Courses?}

Based on Guskey's (2000) Model, evaluating the effectiveness of PD entails evaluating five levels of evaluation information of that PD. Three levels were evaluated in this study which are participants` reactions (satisfaction with the PD experience, e.g., satisfaction with materials and activities), participants' learning, and participants' use of new knowledge and skills

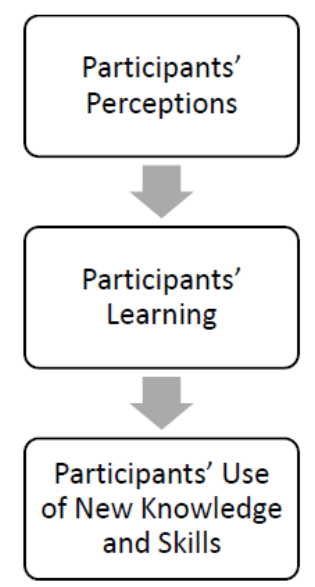

Figure 2. The Three Levels of Evaluation Information (Guskey's (2000) Model)

Therefore, the following sub research questions were addressed to evaluate these three levels and thus to answer the main research question of the study:

a- What are teachers' perceptions of the features of the OPD courses? (Features include likability, content, duration, structure, and interaction.)

b- What is the impact of OPD courses on teachers' learning?

c- How can OPD courses enhance teachers' classroom practices?

\subsection{The First Sub-Research Question}

\subsubsection{What Are the Teachers' Perceptions of the Features of the OPD courses?}

In order to answer the first sub research question, teachers were asked to rate their level of agreement with statements that described their OPD experience, the content, duration and the structure of the courses, and the effect of lack of interaction on their experience. To get a deeper understanding of teachers' responses, the percentages of the positive, neutral, and negative responses of each item were calculated and for ease of presentation and discussing the results, the researcher combined the two positive points (strongly agree, agree), because they generally represent the agreement of teachers. The same procedure was applied to the negative points (disagree, strongly disagree) because they generally represent the disagreement of teachers. The results are presented in (Table 3).

More than half of the teachers (57. $7 \%$ ) identified their OPD experience as a positive experience. While less than half of the teachers expressed that their times in the OPD were well spent (40. $4 \%$ ). In addition, the majority of teachers agreed on the usefulness of the content $(75 \%)$, however, less than half of the teachers agreed that the content of the courses met their needs $(48.1 \%)$. Also, a higher percentage of the teachers agreed that the courses were long enough for them to engage with the ideas, $(61.6 \%)$, on the contrary, only $28.8 \%$ of teachers agreed that the online courses were short. In relation to teachers' perceptions of the structure of the online courses, about half of the teachers $(53.8 \%)$ agreed that the structure was conducive to learning, however, only $32.7 \%$ agreed that the navigation process was difficult.

On the other hand, teachers seemed satisfied with the presentation of the content, as $78.8 \%$ of the respondents reported that the content was presented in an appropriate sequence, and $71.2 \%$ reported that the content was presented clearly to assist their understanding. Finally, slightly more than half of the teachers agreed that the lack of interaction made the OPD less attractive $(53.9 \%)$, while less than have of the teachers agreed that this lack of interaction made the OPD less effective (42.3\%). 
Table 3. Percentages of Positive, Neutral, and Negative Responses of the Items 1-12

\begin{tabular}{|c|c|c|c|}
\hline Items & Agree & $\begin{array}{l}\text { Neither agree } \\
\text { nor disagree }\end{array}$ & Disagree \\
\hline 1- Online courses were generally a positive experience. & $57.7 \%$ & $32.7 \%$ & $9.6 \%$ \\
\hline 2- My time in the online courses was well-spent (Lowden, 2005). & $40.4 \%$ & $36.5 \%$ & $23.1 \%$ \\
\hline 3- The content of the courses was useful. & $75 \%$ & $19.2 \%$ & $5.8 \%$ \\
\hline 4- The content of the courses met my needs. & $48.1 \%$ & $23.7 \%$ & $19.3 \%$ \\
\hline $\begin{array}{l}\text { 5- The online courses were long enough for me to engage with the } \\
\text { ideas (Main \& Pendergast, 2015). }\end{array}$ & $61.6 \%$ & $25 \%$ & $13.5 \%$ \\
\hline 6- The allotted time to complete the courses was short. & $28.8 \%$ & $38.5 \%$ & $32.7 \%$ \\
\hline $\begin{array}{l}\text { 7- The structure of the courses was conducive (facilitative) to learning } \\
\text { (Rizzuto, 2015). }\end{array}$ & $53.8 \%$ & $36.5 \%$ & $9.6 \%$ \\
\hline $\begin{array}{l}\text { 8- The navigation process was difficult (moving from one activity or } \\
\text { web page to another) (Rizzuto, 2015). }\end{array}$ & $32.7 \%$ & $26.9 \%$ & $40.4 \%$ \\
\hline $\begin{array}{l}\text { 9- The content of the courses was presented in an appropriate sequence } \\
\text { (Rizzuto, 2015). }\end{array}$ & $78.8 \%$ & $19.2 \%$ & $1.9 \%$ \\
\hline $\begin{array}{l}\text { 10- The content of the courses was presented clearly to assist my } \\
\text { understanding (Rizzuto, 2015). }\end{array}$ & $71.2 \%$ & $25 \%$ & $3.8 \%$ \\
\hline $\begin{array}{l}\text { 11- Lack of online interaction and communication with trainers and } \\
\text { other teachers via chat, forum, etc, makes OPD courses less attractive. }\end{array}$ & $53.9 \%$ & $25 \%$ & $21.2 \%$ \\
\hline $\begin{array}{l}\text { 12- Lack of online interaction and communication with trainers and } \\
\text { other teachers via chat, forum, etc, makes OPD courses less effective. }\end{array}$ & $42.3 \%$ & $21.2 \%$ & $36.6 \%$ \\
\hline
\end{tabular}

\subsection{The Second Sub-Research Question}

\subsubsection{What is the Impact of OPD Courses on Teachers' Learning?}

Teachers were asked to rate their level of agreement with statements that described their learning in the OPD courses in order to answer the second sub research question. About half of the teachers $(53.9 \%, 53.9 \%, 53$. $8 \%$ ) reported that they have learned practical instructional strategies, new knowledge and skills, and new concepts connected to prior knowledge. However, only 38. $4 \%$ expressed that they have learned the theories behind the teaching practices.

Table 4. Percentages of Positive, Neutral, and Negative Responses of the Item 13-16

\begin{tabular}{|c|c|c|c|}
\hline Items & Agree & $\begin{array}{l}\text { Neither agree nor } \\
\text { disagree }\end{array}$ & Disagree \\
\hline $\begin{array}{l}\text { 13- Because of the online courses, I have learned practical } \\
\text { instructional strategies (Lowden, 2005). }\end{array}$ & $\begin{array}{l}53 . \\
9 \%\end{array}$ & $23.1 \%$ & $23 \%$ \\
\hline $\begin{array}{l}\text { 14- Because of the online courses, I have learned new knowledge } \\
\text { and skills (Lowden, 2005). }\end{array}$ & $\begin{array}{l}53 . \\
9 \%\end{array}$ & $30.8 \%$ & $15.4 \%$ \\
\hline $\begin{array}{l}\text { 15- Because of the online courses, I have learned the theories behind } \\
\text { the teaching practices (Lowden, 2005). }\end{array}$ & $\begin{array}{l}38 . \\
4 \%\end{array}$ & $28.8 \%$ & $32.7 \%$ \\
\hline $\begin{array}{l}\text { 16- Because of the online courses, I have learned new concepts } \\
\text { connected to prior Knowledge (Lowden, 2005). }\end{array}$ & $\begin{array}{l}53 . \\
8 \%\end{array}$ & $25 \%$ & $21.1 \%$ \\
\hline
\end{tabular}

\subsection{The Third Sub-Research Question}

\subsubsection{How can OPD Courses Enhance Teachers' Classroom Practices?}

Regarding the third sub research question, less than half of the teachers agreed with the statements; (After I have participated in the online, I usually implement/apply new instructional strategies (48. $1 \%)$, and I usually make long-lasting changes in my teaching (44. $2 \%$ ). Teachers also indicated a low level of agreement (38.5\%) with the statement (I usually become committed to new teaching strategies). However, more than half of the teachers (61. $6 \%$ ) reported that they usually note positive changes in their teaching after participating in the online courses. 
Table 5. Percentages of Positive, Neutral, and Negative Responses of the Item 17- 20

\begin{tabular}{llll}
\hline Items & Agree & $\begin{array}{l}\text { Neither agree nor } \\
\text { disagree }\end{array}$ & Disagree \\
\hline $\begin{array}{l}\text { 17- After I have participated in the online courses, I usually } \\
\text { implement/apply new instructional strategies (Lowden, 2005). }\end{array}$ & $\begin{array}{l}4 \% .8 \% \\
1 \%\end{array}$ & $21.2 \%$ \\
18- After I have participated in the online courses, I usually become & 38. & $38.5 \%$ & $23.1 \%$ \\
committed to new teaching strategies (Lowden, 2005). & $5 \%$ & & $17.3 \%$ \\
19- After I have participated in the online courses, I usually note & 61. & $21.2 \%$ & \\
positive changes in my teaching (Lowden, 2005). & $6 \%$ & & $23.1 \%$ \\
20- After I have participated in the online courses, I usually make & 44. & $32.7 \%$ & \\
long-lasting changes in my teaching (Lowden, 2005). & $2 \%$ & & \\
\hline
\end{tabular}

\subsection{Discussion of Findings}

In order to answer the main research question of the study (What are teachers' perceptions of the effectiveness of the OPD courses), three sub-research questions were addressed:

a- What are teachers' perceptions of the features of the OPD courses? (Features include likability, content, duration, structure, and interaction.)

b- What is the impact of OPD courses on teachers' learning?

c- How can OPD courses enhance teachers' classroom practices?

\subsection{The First Sub-Research Question}

\subsubsection{What are Teachers' Perceptions of the Features of the OPD Courses?}

Features include likability, content, duration, structure, and interaction. The findings in response to this research question indicated limited positive teachers' perceptions of these features. In relation to the likeability of the courses, about half of the teachers responded positively to the following items in the questionnaire; online courses were generally a positive experience, and my time in the online courses was well-spent, which implies limited positive perceptions to the online courses experience. On the other hand, high positive perceptions were reported to the usefulness of the content. However, less than half of the teachers agreed that the content met their needs. Regarding the duration, the results showed that slightly more than half of the teachers considered the duration sufficient.

Findings suggested that there were some drawbacks of the online courses which are irrelevant content and insufficient duration. These drawbacks contradicted the core features of effective professional development that identified by Desimone (2009) which includes: content focus, coherence, and duration. Content focus means that PD should focus on the skills and knowledge that is needed to carry out day-to-day teaching, duration means that activities of PD should have sufficient duration to allow engagement and knowledge and instructional change, and coherence means the relevance of the professional development to the classroom reality (Main \& Pendergast, 2017).

Additionally, the core features of effective PD included active learning (e.g. engaging in practice and discussion), and collective participation of the teachers from the same school to foster discourse and interaction, "which can be a powerful form of teacher learning" (Desimone', 2009, p. 184). Although the OPD courses were collective, there was a lack of interaction among teachers which results in individual passive learning. Findings of the questionnaire showed that about half of the teachers reported that the lack of interaction in the online courses with trainers and other teachers made the online courses less effective and attractive. This finding indicated that teachers were aware of the significance of online learner-learner interaction which is described by Moore (1989) as "an extremely valuable resource for learning" (p. 4). Additionally, Kabilan, et. al. (2011) found that online collaboration was reported by the teachers as a valuable opportunity to exchange and share their teaching knowledge and experiences.

Another feature that is unique to OPD and should be considered when examining the effectiveness of any OPD program is the interface. The researcher examined teachers' perceptions of the interface of the courses because a successful interaction depends highly on learners' feeling of comfort when working with the delivery system, and learners cannot interact with content if they are not able to interact with the interface (Hillman et al., 1994). Although teachers seemed satisfied with the presentation of the content, only about half of the teachers agreed that the structure of the courses was conducive to learning. 


\subsection{The Second and Third Sub-Research Questions}

\subsubsection{What is the Impact of OPD Courses on Teachers' Learning?}

\subsubsection{How can OPD Courses Enhance Teachers' Classroom Practices?}

About half of the teachers reported that they learned and used the new knowledge, skills, and instructional strategies of the OPD courses. However, it is found in the literature that OPD programs had a significant positive impact on teachers' knowledge and instruction (e.g. Silvia, 2015; McCall, 2018). Silvia (2015) examined teachers' perceptions of the Coursera platform for English language teachers OPD. The researcher developed a survey based on Guskey's (2000) model for evaluating PD and sent it to twenty-four teachers from different countries (Turkey, India, Brazil, Russia, Italia USA, and Indonesia). The results showed high positive teachers' reactions and high significant impact on their learning and instruction. McCall (2018) examined perceptions of content teachers in public schools of the United States that include many EL learners towards an OPD program. Teachers confirmed that the online program developed their preparation skills for the lessons that are provided for EL learners in the content classrooms.

There are many reasons for the insignificant effect of OPD on teachers learning and instruction in this study; teachers' negative perceptions of the features of OPD courses might be the main reason. Guskey (2016) commented that "positive reactions from participants are usually a necessary prerequisite to higher-level evaluation results" (P. 33). The inflexible interface of the online courses might be another reason for hindering teachers' learning. According to Hillman et al. (1994), learners cannot interact with content if they are not able to interact with the interface (Hillman et al., 1994).

Additionally, it seems that the OPD courses of this study lacked the adequate core features of effective PD that are identified by Desimone (2009) based on her synthesis of literature. According to Desimone's (2009) model, adequate core features of effective PD lead to increasing teachers' knowledge and skills, and accordingly, changing teachers' instruction which results in improvement of students' learning. Therefore, the lack of these features might influence the effectiveness of the OPD courses, and by extension, teachers' learning. In his study, Garbe (2012) examined the relationship between these core features in an OPD program and teachers' learning. Findings revealed that teachers perceived the online courses to have the core features of effective PD, and they reported that they developed their knowledge and skills as a result of the OPD.

\subsubsection{Limitations and Recommendations for Further Research}

There are some limitations to the present research. Firstly, the sample of the study was limited to female EFL teachers; therefore, future studies of OPD could include male EFL teachers in the Saudi context. Another limitation is that the researcher examined one OPD program in the Saudi context, and more OPD programs could be examined in further studies. Additionally, due to the time constraints of the study, the researcher examined only three levels of information in Guskey's (2000) evaluative model. Examining the five levels of information is recommended in future research. Finally, future qualitative research is recommended.

\section{References}

Alimirzaee, H., \& Ashraf, H. (2016). On the Effect of Online Peer Knowledge Sharing on Lranian EFL Teachers' Professional Development. Theory and Practice in Language Studies, 6(1), 134-146. https://doi.org/10.17507/tpls.0601.18

Creswell, J. W. (2014). Research Design: Qualitative, Quantitative, and Mixed Methods Approaches (Fourth ed.). Boston: SAGE Publications.

Desimone, L. M. (2009). Improving Impact Studies of Teachers' Professional Development: Toward Better Conceptualizations and Measures. Educational Researcher, 38(3), 181-199. https://doi.org/10.3102/0013189X08331140

Dörnyei, Z. (2007). Research Methods in Applied Linguistics: Quantitative, Qualitative, and Mixed Methodologies. Oxford: OUP Oxford.

Elmabruk, R. (2009). Using the Internet to Support Libyan In-Service EFL Teachers' Professional Development. (Doctoral Dissertation ), University of Nottingham, (11038).

Garbe, A. Y. (2012). Teachers' Perceptions of Online Professional Development in Literacy. (Doctoral Dissertation), Edgewood College. Ann Arbor, Michigan: ProQuest Dissertations Publishing.

Guskey, T. R. (2002). Does It Make a Difference? Evaluating Professional Development. Educational Leadership, 59(6), 45-51. 
Guskey, T. R. (2016). Gauge Impact with 5 Levels of Data. Journal of Staff Development, 37(1), 32-37.

Guskey, T. R., \& Sparks, D. (2000). Evaluating Professional Development. Thousand Oaks, California: Corwin Press.

Hillman, D. C., Willis, D. J., \& Gunawardena, C. N. (1994). Learner-interface interaction in distance education: An extension of contemporary models and strategies for practitioners. American Journal of Distance Education, 8(2), 30-42. https://doi.org/10.1080/08923649409526853

Jumani, N. B., \& Zai, Z. I. Y. (2009). Distance Teacher Education in Pakistan. Quarterly Review of Distance Education, 10(4), 381- 389.

Kabilan, M. K., Adlina, W. F. W., \& Embi, M. A. (2011). Online collaboration of English language teachers for meaningful professional development experiences. English Teaching: Practice and Critique, 10(4), 94-115.

Kabilan, M. K., \& Rajab, B. M. (2010). The Utilisation of the Internet by Palestinian English Language Teachers Focusing on Uses, Practices and Barriers and Overall Contribution to Professional Development. International Journal of Education and Development using Information and Communication Technology, $6(3), 56-72$.

Kirkpatrick, D., \& Kirkpatrick, J. (2006). Evaluating Training Programs: The Four Levels (Third ed.). San Francisco: Berrett-Koehler Publishers.

Liu, M.-H. (2012). Discussing Teaching Videocases Online: Perspectives of Preservice and Inservice EFL Teachers in Taiwan. Computers \& Education, 59(1), 120-133.

https://doi.org/10.1016/j.compedu.2011.09.004

Magidin de Kramer, R., Masters, J., O'Dwyer, L. M., Dash, S., \& Russell, M. (2012). Relationship of Online Teacher Professional Development to Seventh-Grade Teachers' and Students' Knowledge and Practices in English Language Arts. The Teacher Educator, 47(3), 236-259.

https://doi.org/10.1080/08878730.2012.685795

Main, K., \& Pendergast, D. (2015). Core Features of Effective Continuing Professional Development for the Middle Years: A Tool for Reflection. Research in Middle Level Education Online, 38(10), 1-18. https://doi.org/10.1080/19404476.2015.11658177

McCall, A. (2018). Teacher perceptions of online SIOP® professional development. (Doctoral Dissertation), University Of Maryland. Maryland, U. S.. https://doi.org/10.13016/M2QJ7820J

Moore, M. G. (1989). Editorial: Three types of interaction. American Journal of Distance Education, 3(2), 1-7. https://doi.org/10.1080/08923648909526659

Murugaiah, P., Azman, H., Ya'acob, A., \& Thang, S. M. (2010). Blogging in Teacher Professional Development: Its Role in Building Computer-Assisted Language Teaching Skills. International Journal of Education and Development using Information and Communication Technology, 6(3), 73-87.

Pallant, J. (2011). SPSS Survival Manual: A Step by Step Guide to Data Analysis Using the SPSS Program (Fourth ed.). Sydney, NSW: Allen \& Unwin.

Reeves, T. D., \& Pedulla, J. J. (2011). Predictors of Teacher Satisfaction with Online Professional Development: Evidence from the USA's E-Learning for Educators Initiative. Professional Development in Education, 37(4), 591-611. https://doi.org/10.1080/19415257.2011.553824

Rizzuto, M. (2015). Design and Evaluation of Self-Paced Online Faculty Development. (Doctoral disseration ), University of Florida. Ann Arbor, Michigan: ProQuest Dissertations Publishing.

Sener, J., \& Hawkins, R. L. (2007). Factors Affecting Completion Rates in Asynchronous Online Facilitated Faculty Professional Development Courses. International Journal of Instructional Technology and Distance Learning, 4(12), 29-44.

Silvia, A. (2015). "Coursera" Online Course: A Platform for English Teachers' Meaningful and Vibrant Professional Development. TEFLIN Journal - A Publication on the Teaching and Learning of English, 26(2), 228-246. https://doi.org/10.15639/teflinjournal.v26i2/228-246

Stahl, L. D. (2012). Transformative Professional Development through the Eyes of Jack Mezirow and Thomas Guskey. (Doctroal dissertation), University of Denver. Ann Arbor, Michigan: ProQuest Dissertations Publishing.

Taylor, J. M. (2011). Characteristics of Effective Online Professional Development: A Case Study Analysis of an 
Online Professional Development Course Offered via Blackboard. (Doctroal dissertation), University of Pittsburgh. Ann Arbor, Michigan: ProQuest Dissertations Publishing.

\section{Copyrights}

Copyright for this article is retained by the author(s), with first publication rights granted to the journal.

This is an open-access article distributed under the terms and conditions of the Creative Commons Attribution license (http://creativecommons.org/licenses/by/4.0/). 